\title{
Diatoms Distribution and its Paleoenvironmental Implications in Pulicat Lagoon Tamil Nadu South East Coast of India
}

\author{
Shubhangi T. Fulmali ${ }^{1}$, S. M. Hussain ${ }^{2}$, Sunitha D. ${ }^{3}$, S. K. Humane ${ }^{4}$ \\ ${ }^{1,2}$ Department of Geology, University of Madras \\ ${ }^{3,4}$ P.G.Department of Geology, RTM Nagpur University
}

\begin{abstract}
To know the rate of sediementation and eutrophication processes in the Pulicat lagoon,a short core with a length of $1 m$ is retrieved from the lake and subsampled in to 35 subsamples with an interval of $3 \mathrm{~cm}$ each. All the samples are subjected to standard microplaeontological techniques to the study. The study area consists of 35 species belonging to 35 genera, 25 families, 3 suborder, 2 subclasses and 2 classes have been identified throughout the core. Grammatophora oceanica Cocconies heteroidea, Opephora swartzii, Mastogloia baldjikiana, Petroneis marina and Tryblionella hungarica were the abundant species and Nitzschia palea as well as Nitzschia sigma are least present in the entire core. On the basis of textural analysis, a litholog is prepared and divided into three zones i.e, Zone I, Zone II and Zone III from bottom to top. Zone I and Zone III are dominated by sand which indicates the higher energy condition and Zone II shows the calm environment. Zone II showing the dominance of clayey sand, may be due the distribution of mangrove during this period of deposition of sediments. Organic matter is relatively less, it may be because of higher accumulation of sand particle which are carried out by the river in to the lagoon. Deposition of sand in the lagoon favours the significant growth of diatom.
\end{abstract}

Keywords: Pulicat Lagoon, Diatoms, Sand-silt-clay, Trace elements

\section{Introduction}

Diatoms are universally distributed in all types of aquatic environment with others being endemic to specific regions (Potapova and Charles, 2002). They are very sensitive to changes in the salt content of water and can be used as indicator of the degree of salinity. Diatoms are especially good indicators of the environmental integrity of lotic ecosystem and they multiply rapidly, maintaining a dynamic population of varying size depending on the prevailing environmental conditions. Diatoms are the most species rich group of algae with tens of thousands of species (Mann, 1999). Round(1993) states that there are currently over 260 genera of living diatoms with over 100,000 species. Till date a total number of 173 species of diatoms belonging to 24 genera have been reported from various regions of India (Gandhi 1953; Gandhi 1956, 1959, 1967; Sarode \& Kamat $1979,1983)$, however, all these work have been confined to certain specific localities of western and southern India, e.g. Maharashtra, Gujarat and Karnataka states.

\section{Study Area}

The Pulicat lake, locally known as Pralaya Kaveri or Kaveri and also "Palaverkadu" (Tamil ) is a vast coastal lagoon, spreading over the southern Nellore District of A.P. and the northern fringe of Chengalput District of Tamil Nadu.

The length of the lake at its maximum is about $59 \mathrm{Km}$. The width varies from $0.2 \mathrm{Km}$ to $17.5 \mathrm{Km}$. The area covered by the lake 8459.24 sq. $\mathrm{Km}$. The lake is located in between $13^{\circ}$ $24^{\prime}$ to $13^{\circ} 43^{\prime} \mathrm{N}$ latitude and $80^{\circ} 03^{\prime}$ to $80^{\circ} 18^{\prime} \mathrm{E}$ longitudes. Its area under full submergence is about $459 \mathrm{sq}$. Km. of which about 6 sq. $\mathrm{Km}$ is in Tamil Nadu, on its eastern border there is elongated sand spit by name Srihari which separates the lake from Bay of Bengal.

The lake is shallow sloping north to south and west to east. The average depth of water in the lake is little over one meter. The total run off from the fresh water sources is estimated at 3,02,542 cubic meters. There would be sea water entering during high tides and out-flow of lake water takes place during the low tides and floods.

The lake is fed by rivers like Swarnamukhi, Kalangi, Royyalakaluva, Kalleru and Arani, but human interventions on their upstream resulted in almost nil in-flows into the lake. When Buckingham Canal passing between the lake and sand spit was active, some in flows were taking place from River Swarnamukhi and River Ennuru. But, now it is choked due to silting over long reaches. There are some unnamed streams between Nayudupeta and Arambakkam, which end up in the Pulicat Lake.

The sea water enters the lake through the ebb and tide of the sea by four routes called gateways (1) Pamanjeri (2) Vepenjeri (3) Pulin Jeri (4) Nakkala doruvu. The lake empties its freshest into Bay of Bengal, through its mouths, one each on either side of the sand spit. The one lying in the southeast corner of the lake is a regular one, while the other at the north-eastern point is an occasional one. 
International Journal of Science and Research (IJSR)

ISSN (Online): 2319-7064

Index Copernicus Value (2016): 79.57 | Impact Factor (2015): 6.391

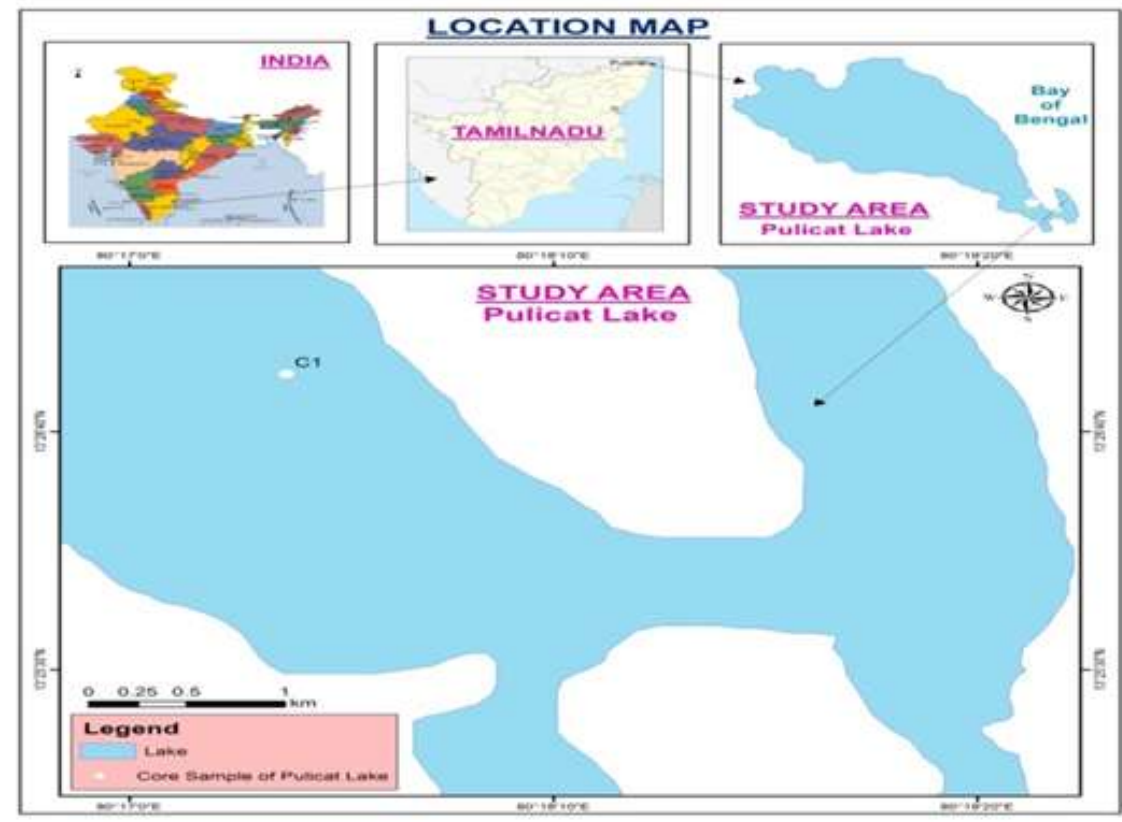

Figure 1: Location Map of Study Area

\section{Materials and Methods}

To study the geochemical processes and anthropogenic influences on the diatoms as well as sediments of the Pulicat Lake, one core sample of $1 \mathrm{~m}$ length ( latitude $13^{\circ} 24^{\prime} 56^{\prime \prime} \mathrm{N}$ and $80^{\circ} 17^{\circ} 26^{\prime}$ 'E) has been collected (Fig.1). This core is sub-sampled at $3 \mathrm{~cm}$ interval. All the 35 sediment samples obtained (PKL1-PKL35) were subjected to standard micropaleontological techniques and various sedimentological techniques so as to record the occurrence of diatoms and to know the nature of the collected sediment samples.

Organic matter in the sediment samples were determined by adopting a methodology suggested by Piper (1947), Gaudette et al (1974) Walkey-Black method (1974), adopted and modified from ML combination of sieving and pipette procedure, the latter in accordance with Krumbein and Pettijhon (1938). Trilinear plots were prepared and description has been given based on Trefethen's (1950) textural nomenclature.

For the diatom analysis, $5 \mathrm{gm}$ sample from each interval of sample was taken .These sediments were treated with $10 \%$ $\mathrm{HCl}$ to remove calcium carbonate and washed several times with distilled water. Afterward's the sample was boiled in $30 \%$ (15 mins) $\mathrm{H}_{2} \mathrm{O}_{2}$ in order to digest the organic matter, the samples were washed several times with distilled water. Finally the samples were ready to make permanent microscope slide (Batterbee, 1986). The percentage of the diatom has been calculated by given formula.

Daitom\% $=$ Diatom present in each sample/Total diatoms in all samples*100
Table 1: Trace element concentration, Diatom\% and Sandsilt-clay ratio of the Pulicat Lake

\begin{tabular}{|c|c|c|c|c|c|}
\multicolumn{7}{|c}{ silt-clay ratio of the Pulicat Lake } \\
\hline & \multicolumn{5}{|c|}{ Values in \% } \\
\hline Sample No & Diatom\% & Organic Matter\% & Sand\% & Silt\% & Clay\% \\
\hline PKL1 & 31.26 & 2.16 & 92.76 & 7.172 & 0.068 \\
\hline PKL2 & 12.72 & 0.1 & 90.02 & 9.892 & 0.088 \\
\hline PKL3 & 5.00 & 1.23 & 86.76 & 0.38 & 12.86 \\
\hline PKL4 & 4.91 & 1.13 & 83.8 & 0.44 & 15.76 \\
\hline PKL5 & 2.86 & 1.24 & 86.82 & 0.34 & 12.84 \\
\hline PKL6 & 6.72 & 1.34 & 80.98 & 0.38 & 18.64 \\
\hline PKL7 & 6.36 & 1.44 & 79.62 & 0.4 & 19.98 \\
\hline PKL8 & 6.27 & 2.06 & 83.22 & 9.42 & 7.36 \\
\hline PKL9 & 1.68 & 0.92 & 83.8 & 0.52 & 15.68 \\
\hline PKL10 & 1.82 & 1.75 & 79.34 & 0.48 & 20.18 \\
\hline PKL11 & 0.41 & 1.24 & 84.08 & 0.44 & 15.48 \\
\hline PKL12 & 0.73 & 1.96 & 78.64 & 0.36 & 21 \\
\hline PKL13 & 0.36 & 1.23 & 89.4 & 6.78 & 3.82 \\
\hline PKL14 & 0.77 & 1.23 & 79.46 & 0.46 & 20.08 \\
\hline PKL15 & 1.45 & 1.85 & 76.3 & 0.54 & 23.16 \\
\hline PKL16 & 0.77 & 1.85 & 83.7 & 13 & 3.3 \\
\hline PKL17 & 0.50 & 1.85 & 78.06 & 16.98 & 4.96 \\
\hline PKL18 & 0.41 & 1.96 & 62.26 & 7.56 & 30.18 \\
\hline PKL19 & 3.13 & 1.33 & 68.74 & 0.56 & 30.7 \\
\hline PKL20 & 1.04 & 0.72 & 70.66 & 0.56 & 28.78 \\
\hline PKL21 & 0.50 & 0.2 & 69.22 & 0.56 & 30.22 \\
\hline PKL22 & 1.27 & 0.2 & 41.84 & 0.6 & 57.56 \\
\hline PKL23 & 1.50 & 0.03 & 43.74 & 0.58 & 55.68 \\
\hline PKL24 & 1.50 & 1.13 & 59.48 & 0.54 & 39.98 \\
\hline PKL25 & 1.23 & 0.72 & 80.06 & 0.58 & \\
\hline PKL26 & 2.82 & 1.03 & 94.76 & 0.58 & 4.66 \\
\hline PKL27 & 1.18 & 0.72 & 87.28 & 0.56 & 12.16 \\
\hline PKL28 & 0.23 & 0.82 & 89.54 & 0.52 & 9.94 \\
\hline PKL29 & 0.27 & 0.4 & 91.54 & 0.26 & 8.2 \\
\hline PKL30 & 0.05 & 1.1 & 92.48 & 0.5 & 7.02 \\
\hline PKL31 & 0.09 & 1.1 & 81.98 & 0.56 & 17.46 \\
\hline PKL32 & 0.05 & 1.03 & 91.76 & 0.56 & 7.68 \\
\hline PKL33 & 0.05 & 0.51 & 88.76 & 0.56 & 10.68 \\
\hline PKL34 & 0.05 & 0.61 & 92.04 & 0.32 & 7.64 \\
\hline PKL35 & 0.05 & 0.51 & 80.32 & 0.12 & 19.56 \\
\hline Max & 31.36 & 2.16 & 94.76 & 16.98 & 57.56 \\
\hline Min & 0 & 0.03 & 41.84 & 0.12 & 0.068 \\
\hline Average & & 1.11 & 80.09 & 2.40 & 17.51 \\
\hline
\end{tabular}

\section{Volume 6 Issue 12, December 2017}

\author{
www.ijsr.net
}

Licensed Under Creative Commons Attribution CC BY 


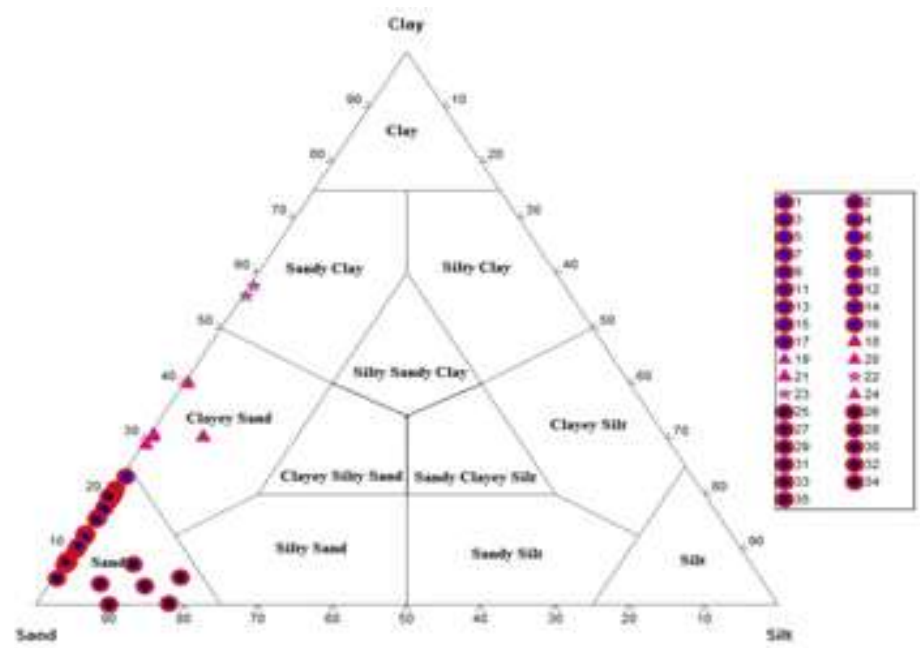

Figure 2: Trilinear plot of Sand-Silt-Clay ratio of Pulicat Lake, Tamil Nadu

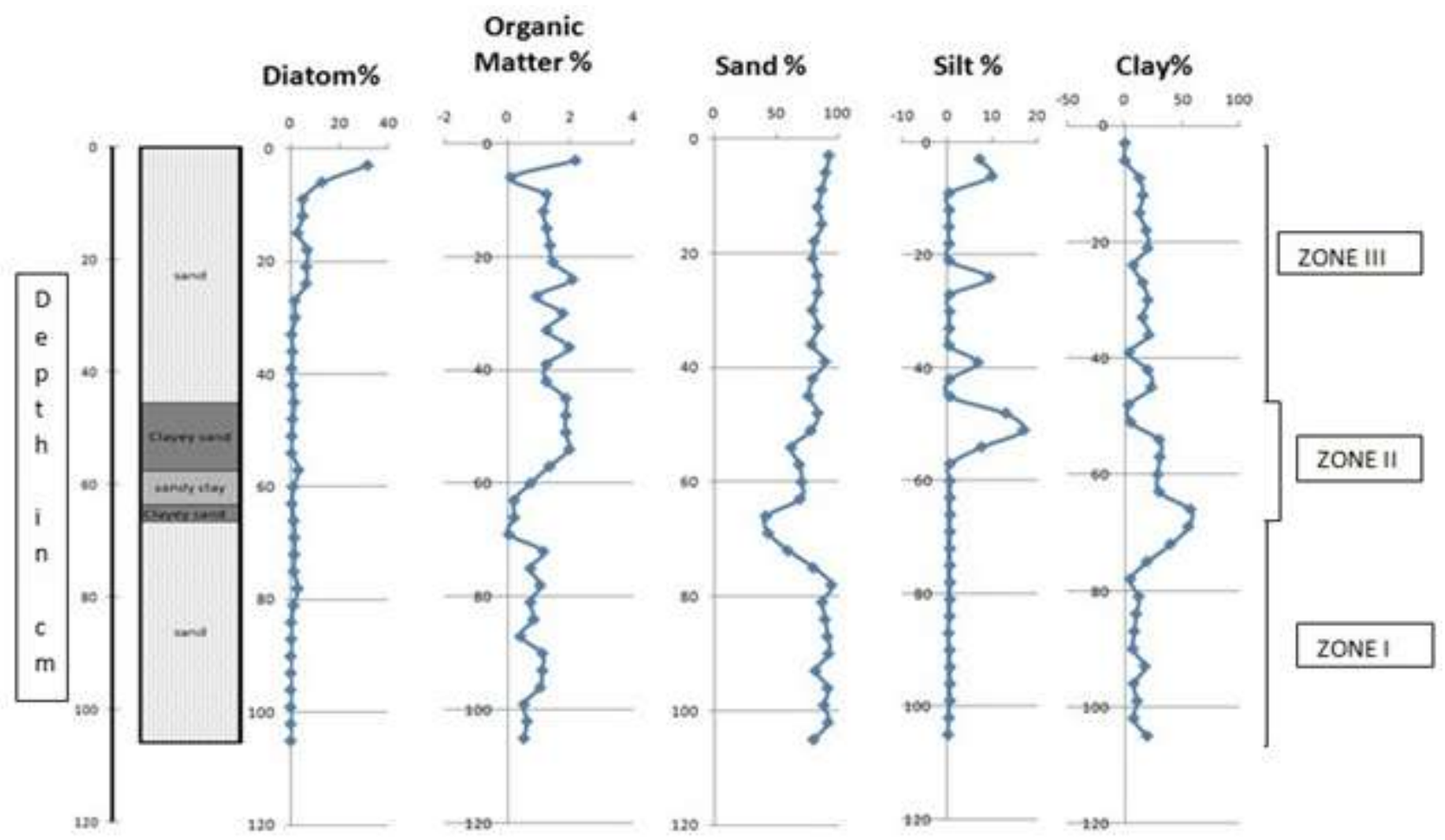

Figure 3: Comparison between Diatom and sedimentological parameters of the Pulicat Lake, Tamil Nadu

\section{Results and Discussion}

\section{Sediment Characteristics}

Grain size parameters had been used to characterize the sediments in the shelf environment (Nittrouer, 1983, 1984); moreover, the bottom topography of any modern environment is affected by the distribution and transport processes of the sediments present in the area (McCave, 1972). According to Koldijk (1968), analyses of textural parameters are indicators of the environmental condition as they are environmental sensitive. To establish geochemical processes and anthropogenic activity which influences the diatoms as well as the sediments in the lake, we have studied the core sediment sample from the Pulicat lake and it is found that most of the sediment samples fall in the region of sand and then in clayey sand (Fig.2). The results of textural analysis of core is presented in the Table 1. The average percentage of sand in this core has: $80.092 \%$, silt- $2.401 \%$ and clay- $17.506 \%$. On the basis of textural analysis a litholog prepared and divided into three zones i.e., Zone I, Zone II and Zone III from bottom to top. Zone I and Zone III are dominated by sand which indicates the higher energy condition of deposition and Zone II shows the fine grained clay deposited under the calm environment. Zone II showing the dominance of clayey sand, it may be due the Mangrove distribution during the period in the area and apparently this litholog has compared with the Diatom\% as well as trace elements as shown in the Table 1 and Figures 3.

There are three conditions which are favorable for the deposition of organic matter in lake sediments are, an abundant supply of organic matter, a relatively fast accumulation of organic material particularly fine grains and a small supply of oxygen to the waters in contact with sediments (Sverdrup et al. 1942). On the basis of this, Hussain et al. (2012) has carried out the comparative study

\section{Volume 6 Issue 12, December 2017}

\section{www.ijsr.net}

Licensed Under Creative Commons Attribution CC BY 


\section{International Journal of Science and Research (IJSR) \\ ISSN (Online): 2319-7064 \\ Index Copernicus Value (2016): 79.57 | Impact Factor (2015): 6.391}

of Pulicat Lake and off Palar basin and found that the organic matter for surface sediments ranges from 0.04 to $0.69 \%$ and 0.19 to $1.26 \%$ respectively which favors the maximum population of microfauna which depends mostly on phytoplankton. Organic matter is relatively less, may be because of higher accumulation of sand particle which are carried out by the river in to the lagoon.

\section{Diatom Analysis}

The study area consist of 35 species belonging to 35 genera, 25 families, 3 orders, 2 subclasses and 2 classes have been identified throughout the core. Grammatophora oceanica Ehrenberg, Cocconies heteroidea Hantzsch, Opephora swartzii (Grunow) Petit, Mastogloia baldjikiana Grunow, Petroneis marina (Ralfs in Pritchard) D.G.Mann and Tryblionella hungarica (Grunow) Frenguelli were the abundant species throughout the core (Fig.5 and Fig.6). For the study of sorting out the geochemical processes and anthropogenic influences involved in the diatoms, the abundant species present in the core have been selected.

Cocconies heteroidea Hantzsch is a marine diatom (Suzuki et al. 2001). The proportion of the Cocconies heteroidea is increased in the surface of the lake (Zone III) i.e., top portion of the core from the $0-3 \mathrm{~cm}$ depth. It indicates salinity is more (i.e., seawater input is increased) and oligotrophic condition.

Grammatophora oceanica Ehrenberg is a brackish to marine species (Ehrenberg,1840) begins to increase at about the $84-3 \mathrm{~cm}$ sample from Zone I to Zone III i.e., from bottom to top, and reach near their highest levels at $6 \mathrm{~cm}$ depth which indicates the oligotrophic condition.

Opephora swartzii (Grunow) Petit is a fresh to brackish water benthic form of the lower estuary (John, 2012) found in the Pulicat lake may be transported by rivers.

Mastogloia baldjikiana is a marine, oligotrophic diatom species. According to Robler (2006) Mastogloia sp. indicates the transgression in the Western Baltic Sea i.e., increased in the inflow of saline water.

Petroneis marina (Ralfs in Pritchard) D. G. Mann is a marine species growing in the sea.

Tryblionella hungarica (Grunow) Frenguelli is a fresh and brackish waters, hypertrophic floating or freely motile species (Frenguelli, 1942). Zone I is dominated by Tryblionella hungarica (Grunow). The abundance of species found from (bottom) $81 \mathrm{~cm}$ to $51 \mathrm{~cm}$ (top) depth, after that there is no Tryblionella species occur in the core. This indicates the low salinity as compared to the Top most portion of the core i.e., Zone III.

Nitzschia palea (Kütz.) W. Smith and Nitzschia sigma (Kütz.) W. Smith are least present in the core but the presence of these organic pollution tolerant species in the uppermost part of the Zone III may be due to the sewage effluent in the Pulicat Lake.

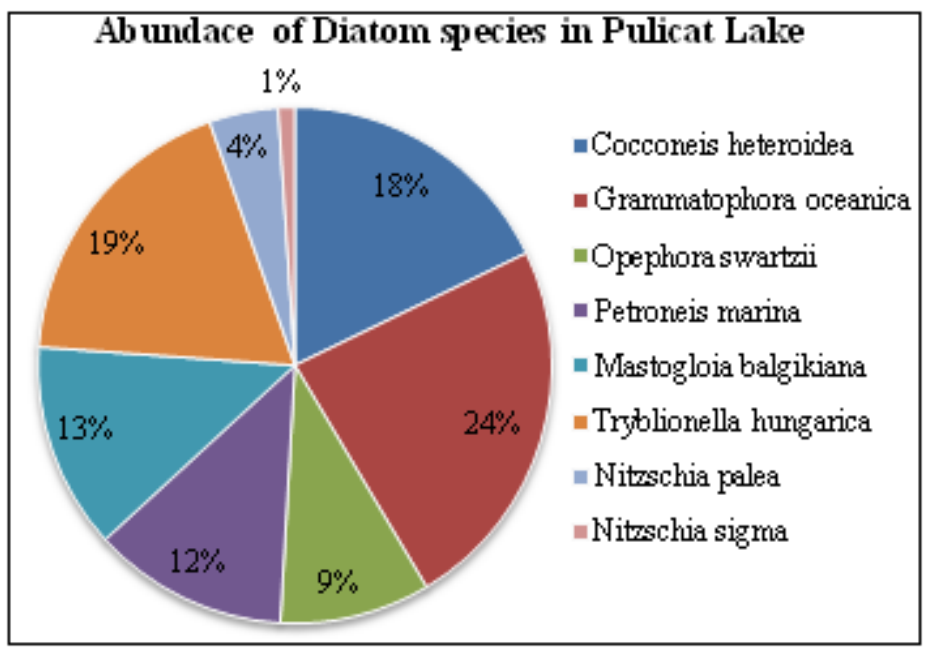

Figure 5: Abundance of Diatom species in \% in Pulicat Lake, Tamil Nadu

Volume 6 Issue 12, December 2017 www.ijsr.net 


\section{International Journal of Science and Research (IJSR) \\ ISSN (Online): 2319-7064}

Index Copernicus Value (2016): 79.57 | Impact Factor (2015): 6.391
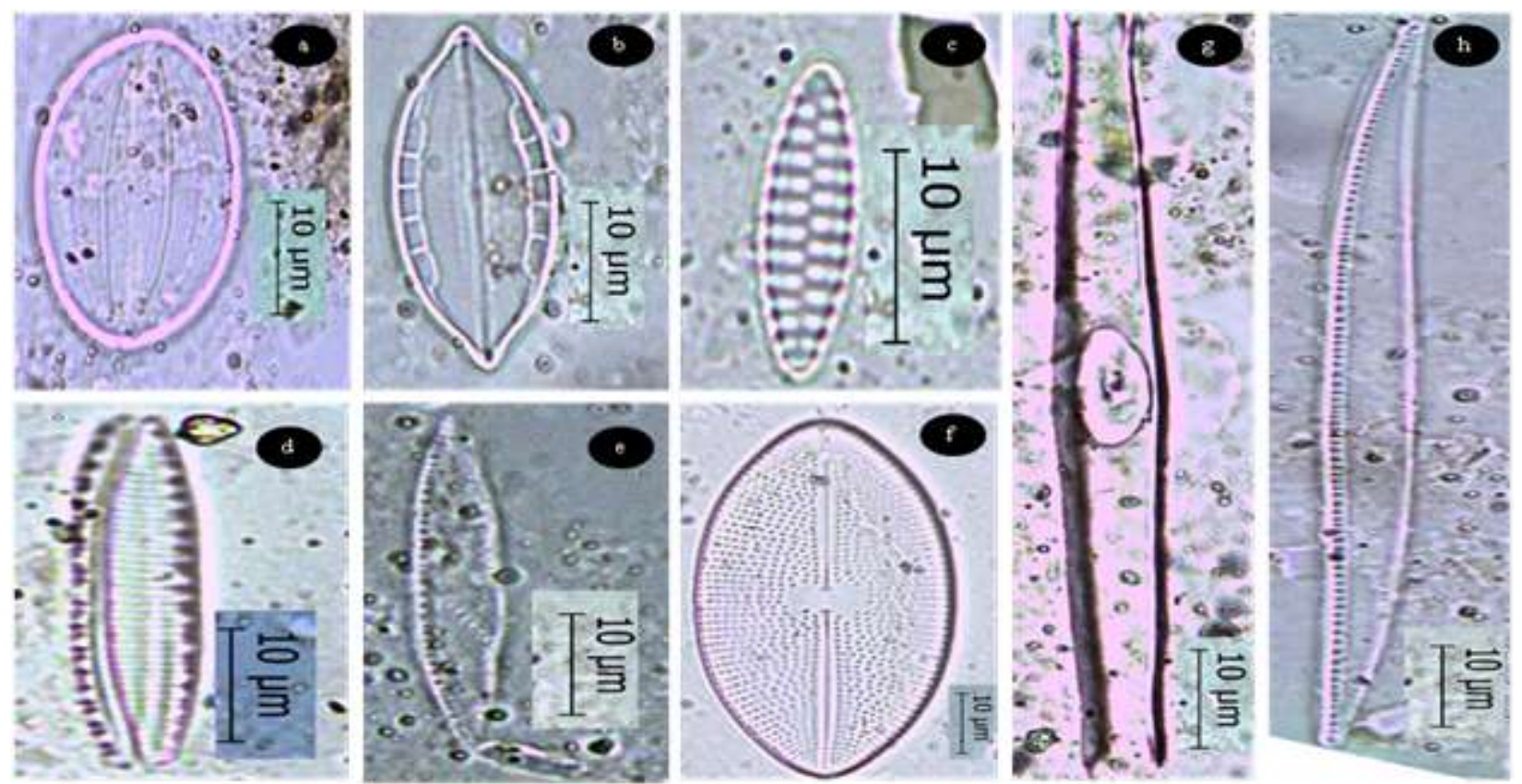

Figure 5: a) Cocconies heteroidea Hantzsch b) Mastogloia baldjikiana Grunow c) Opephora swartzii (Grunow)Petit d) Tryblionella hungarica (Grunow) Frenguelli e) Nitzschia sigma (Kütz.)W.Smith f) Petroneis marina (Ralfs in Pritchard D.G.Mann g) Grammatophora oceanica Ehrenbergh h) Nitzschia palea (Kütz.)W.Smith

\section{Conclusion}

Deposition of sand in the lagoon favours the significant growth of diatom. Siltation_and periodic closure of the bar mouth due to the dynamic process of sediment transport has caused reduction of size and seasonal closure of the mouth of the lake has reduced fresh sea-water exchange and made the lake shallow and turbid.

The results of the present study suggest that, the diatoms species in the core of Pulicat lake was dominated by the brackish water species at the Zone I which indicates the hypertrophic status and marine diatom species at Zone III which indicates the oligotrophic status of the lake. These marine as well as brackish water diatoms species also show their tolerance towards pollutant which is caused by the anthropogenic activity.

\section{Acknowledgement}

Authors are thankful to Dr. S. Ramasamy, Professor and Head, Deaprtment of Geology, University of Madras for his permission to carry out this work. The research has been supported by UGC-CPEPA fellowship for that we are greatly acknowledged. The authors wish to express their gratitude to Dr. S. S. Humane, Assistant Professor, P.G. Department of Geology, R.T.M. Nagpur University, Nagpur for hes suggestions and support during the work. The research is supported by UGC-CPEPA project for for that authors are highly ackonowlwdge Dr. S. Ramasamy, Coordinator, UGC-CPEPA

\section{References}

[1] Battarbee, R.W. 1986. Diatom analyses. In: Handbook of Holocene Paleoecology and Paleohydrology edited by Berglund BE (Wiley, New York): 527-570.
[2] Ehrenberg, C.G. 1840. Erstlich über ausgezeichnete jetzt lebende peruanische und mexikanische MeeresInfusorien, welche mit zur Erläuterung räthselhafter fossiler Formen der Kreidebildung dienen. Bericht über die zur Bekanntmachung geeigneten Verhandlungen der Königlich-Preussischen Akademie der Wissenschaften zu Berlin 1840: 157-162.

[3] Forstner, U. \& W. Salomons, 1980. Trace Metals Analysis on Polluted Sediments, Environmental Technology Letters 1:494.

[4] Frenguelli, J. 1942. Diatomeas del Neuguén (Patagonia). XVII. Contribución al conocimiento de las diatomeas argentinas. Revista del Museo de La Plata (Nueva Serie), Sección Botánica 5(20): 73-219.

[5] Gandhi H.P. 1998. Fresh - water Diatoms of Central Gujarat. Bishen Singh Mahendra Pal Singh, Connaught Place 23-A 1-321.

[6] Gaudette H, W. Flight, L.Toner \& D. Folger 1974. An inexpensive titration method for the determination of organic carbon in recent sediments. Journal of Sedimentary Petrology 44:249-253

[7] Grunow, A. 1862. Die Osterrienchischen Diatomaceen nebst Ancshluss neuen Arten von andern Lokalitaten und einer kritischen Uebersiccht der bisher bekannten Gattungrn und Arten. Verhandlugen der Kaiserlich Koniglichen Zoologisch-Botanischen in Wein 12: 315472,545-588.

[8] Harbison, P. 1986. Mangrove muds- a sink and a source for tarce metals. Marine Pollution Bulletin 17: 246-250.

[9] Huc, A.Y. 1980. Origin and formation of organic matter in recent sediments and its relation to kerogen. In: Durand B. (ed) Kerogen: Matiere organique insoluble de roches sediementaries, Technip, Paris 446-474.

[10] Hussain, S.M., N. Rajeshwara Rao \& P. Mahalakshmi, 2012. A comparative study on distribution of foraminifera and ostracods in the inner shelf off Pulicat and Palar, Tamil Nadu, South East Coast of India. Gondwana Geological Magazine 3:153-162. 


\section{International Journal of Science and Research (IJSR) \\ ISSN (Online): 2319-7064 \\ Index Copernicus Value (2016): 79.57 | Impact Factor (2015): 6.391}

[11] John Jacob, 2014. Recent Advancements in the Application of Diatoms and Lake Sediments in Determining Environmental changes in Water Quality and Paleoclimatic Condition- An introduction to diatoms.

[12] John Jacob. 2012. Diatoms in the Swan River Estuary Western Australia Taxonomy and Ecology.

[13] Koldijk W.S. 1968. Bottom sediments of the Ria de Arosa, Galicia, NW Spain. Leidse. Geol.Meded 37:77134.

[14] Krumbein, W.C. and F.J. Pettinjohn, 1938. Manual of Sedimentary Petrography. D. Appleton Century Co. Inc., New York: 549.

[15]Lazo Pranvera, 2009. Determination of $\mathrm{Cr}$ (VI) in Environmental Samples Evaluating Cr (VI) Impact in a Contaminated Area Impact. Journal of International Environmental Application \& Science 4 (2): 207-213.

[16] McCave, I.N., 1972. Transport and escape of finegrained sediment from shelf areas. In: Swift, D.J.P., Duane, D.B., Pilkey, O.H. (Eds.), Shelf Sediment Transport: Process and Pattern. Dowden, Hutchinson and Ross, New York, 225-247.

[17] Nath, B. N., H. Kunzedorfe \& Pluger W.L. 2000. Influence of Provenance, weathering and sedimentary processes on the elemental ratio of the fine-grained fraction from the Vemmnad lake and the adjoining continental shelf, southwest coast of India. Journal of Sedimentary Research. 70(50):1081-1094.

[18] Nesbitt, K.1996. Theorizing a New Agenda for Architecture: An Anthology of Architectural Theory, 1965-1995.New York: Princeton Architectural Press.

[19] Nittrouer, C.A. 1983. Uptake dissolution and accumulation of Silica near the mouth of Changjian river In: Proceedings of the International Symposium in Sedimentation on continental shelf with special reference to East China Sea, China Ocean Press, Beijing: 235-240.

[20] Nittrouer, C.A., D.J. DeMaster, \& B.A.McKee, 1984. Fine-scale stratigraphy in proximal and distal deposits of sediment dispersal systems in the East China Sea. Marine Geology 61(1): 13-24.

[21] Piper, F.B.1947. Soil and plant analysis. University of Adelaide Press, Aldelaide: 368.

[22] Potapova, M.G. and D.F. Charles. 2002. Benthic diatoms in USA rivers: distributions along spatial and environmental gradients. Journal of Biogeography 29: 167

[23] Robler Doreen, 2006. Reconstruction of the Littorina Transgression in the Western Baltic Sea. Institut für Ostseeforschung Warnemünde Meere swissens chaftliche Berichte Marine Science Reports No. 67:111

[24] Rosund, F.E. and, D.G. Mann 1981. The diatom genus Brachysira. Typification and sepeartion from Anoemoeoneis. Archiv fur Protostekunde 124 (3):221231.

[25] Round,F. E., R.M. Crawford and D.G. Mann, 1990. The Diatoms: Biology and morphology of genera. Cambridge University Press, New York: 747.

[26] Sarode P.T. and Kamat N.D. 1979. Diatoms of Marathwada, Maharashtra-I. Phykos 18 25-32.

[27] Sarode P.T. and Kamat N.D. 1980. Diatoms of Marathwada, Maharashtra-II. Phykos 19 197-203.
[28] Sarode P.T. and Kamat N.D. 1980. The diatomflora of Nagpur, India. Nova Hedwigia 32 797-838.

[29] Suzuki, H., T. Nagumo \& J. Tanaka, 2001. Morphology of the marine epiphytic diatom Cocconeis heteroidea (Bacillariophyceae). Phycological Research 49: 129. 136.

[30] Sverdrup, H.V., M.W. Johnson and R.H. Fleming, 1942.The Oceans. Prentice Hall, New York: 1087.

[31] Trefethen, J.M. 1950. Classification of sediments. American Journal of Science 248: 55- 62.

Volume 6 Issue 12, December 2017

www.ijsr.net

Licensed Under Creative Commons Attribution CC BY 